\title{
6 \\ Pitcairn and the Bounty Story
}

\section{Maria Amoamo}

It is Pitcairn's Island, the setting is $\mathbf{1 7 9 0}$ for the final act of one of the greatest sea dramas of all time, the mutiny aboard His Majesty's Armed Transport Bounty on 28 April 1789. Inch for inch, it is the repository of more history - romantic history, bloody history, bogus history than any other island in the Pacific. ${ }^{1}$

Islands have long held a central place in western cultures' mythical geographies. The following narrative examines Pitcairn Island, the last remaining British overseas territory in the Pacific and the unique heritage that underlies its inception and image. Pitcairn was settled by Bounty mutineers and Tahitians in 1790 and where, today, fewer than 50 Bounty descendants still reside. Discussion highlights key symbolic referents that contribute to a sense of 'exclusivity' of Pitcairn culture and posits 'myth-making' as a key determinant in helping build a sustainable tourism industry for Pitcairn.

Few island peoples in the world could boast the body of literature written about their history, happenings and unique lifestyle than Pitcairn. It has been estimated some 1,200 books, 3,200 magazine and uncounted newspaper articles, documentary films and three major Hollywood movies produced relating to the mutiny on the Bounty

1 Ian M. Ball, 1973, Pitcairn: Children of the Bounty, London: Gollancz, p. 4. 
have accounted for Pitcairn's iconic status. ${ }^{2}$ The story is not myth but has served to mythologise Pitcairn. ${ }^{3}$ Collectively, such texts formulate the gaze over landscape and reveal how place-myth is both shaped and organised through discourse. What becomes relevant to ascertaining the role of myth in relation to the Bounty story is its resilience and mutability. Robert Kirk states of Pitcairners: 'They are the heirs of Odyssean voyages, surging passions, of steamy romance ... Pitcairn lies in the public imagination and the presence of the mutineer's pedigreed descendants perpetuates the island's status as an icon. ${ }^{\prime 4}$ Such musings help foster the Bounty image alongside the community's unique social and cultural inception, thus transferred to its presentday descendants, of whom several keenly exploit this connection as a tourist commodity.

\section{Constructing place: Pitcairn's cultural landscape}

Pitcairn is both marginal in the sense of its remote geographic location and also as a site of illicit action represented by the very act of mutiny. This act marks the island and its inhabitants on the periphery of cultural systems of space. Upon landing the mutineers burned the ship - an act that both ensured their isolation and containment, and some may argue their allegiance to British law. Of note, the ritual performance of 'burning the Bounty' on 23 January is an annual event re-enacted by descendants not only on Pitcairn but also by wider diaspora in Norfolk Island and New Zealand. ${ }^{5}$ Such acts remind us that performances of place are not fixed in inert cartographically coordinated spaces but contingently enacted in an ongoing, complex process involving cultural production. The latter involve

2 Philip Hayward, 2006, Bounty Chords: Music, Dance and Cultural Heritage on Norfolk and Pitcairn Islands, Eastleigh: John Libbey Publishing.

3 As a result of the mutiny, nine mutineers together with 12 Tahitian women and six men landed on Pitcairn in January 1790. The island was not visited by outsiders until 1808, an indication of the remoteness that typifies Pitcairn. Pitcairn became a British possession in 1838 . 4 Robert W. Kirk, 2008, Pitcairn Island, The Bounty Mutineers and their Descendants, A History, Jeffersen, NC: McFarland \& Co, p. 232.

5 In 1856 the entire population was coerced to migrate to Norfolk Island some 3,700 miles to the west. However, some families returned to Pitcairn a few years later and there remain strong cultural ties with Norfolk Island. See Peter Clarke, 1986, Hell and Paradise: The Norfolk, Bounty, Pitcairn Saga, Ringwood: Viking. 
performances of scripting, designing, building and storytelling. ${ }^{6}$ The historical trajectory of settlement in the nineteenth century served to create a Pitcairn identity manifest in isolation, insularity and a sense of exclusivity.

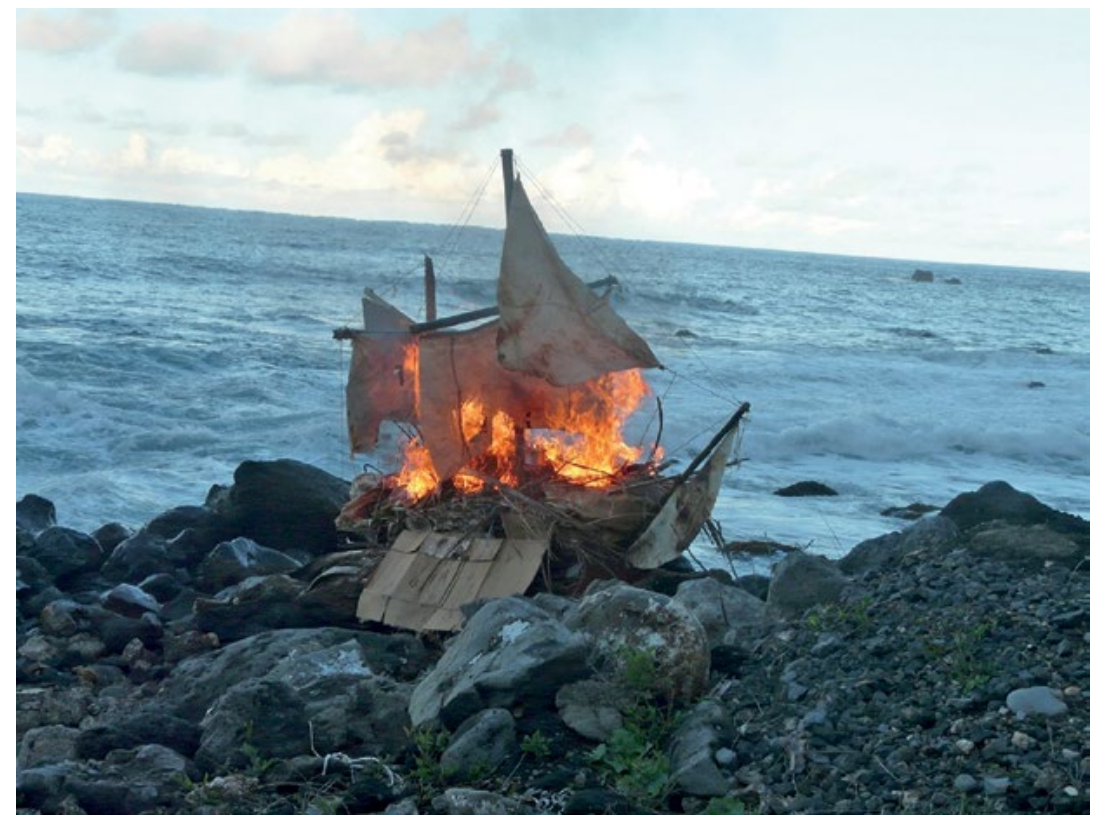

Figure 25. Burning the Bounty.

Source. Photographed by Maria Amoamo, Pitcairn Island, 23 January 2009.

Over time the Bounty settlers would develop life skills particularly adapted to the environment; speak an exclusive 'Pitkern' language - a creole mixture of eighteenth-century English and Tahitian - and operate their own unique form of self-government. Today most residents are Seventh Day Adventists, having converted to the faith in 1886 following the visit of an American missionary of that persuasion. Critics have argued that places are more than simply geographic sites with definitive physical and textual characteristics; places are also settings (or locales) in which social relations and identities are constituted. ${ }^{7}$ As such, we need to acknowledge the

6 Jonas Larsen, 2012, 'Performance, space and tourism', in The Routledge Handbook of Tourism Geographies, ed. Julie Wilson, pp. 67-73, Abingdon, Oxon: Routledge.

7 John Agnew, 1987, Place and Politics: The Geographical Mediation of State and Society, London: George Allen and Unwin. 
complex intersection of the senses in people's encounters with places. ${ }^{8}$ An example of this analogy is the culturally layered landscape of Pitcairn. Upon arrival the island was a blank slate on which to inscribe place names and suggest the mutineers and their descendants saw Pitcairn as a new independent world, not a replication of Britain or Tahiti. The cultural landscape of Pitcairn tells of the relationships between people and place. ${ }^{9}$ Place names depict past events, reminders of people and actions. Lack of allusion to anything British found in other colonial outposts is notable, perhaps not surprising given the mutineers rebelled against such heritage in the very act of mutiny. Examples include 'Bang on iron', the site of the Bounty's forge, and 'Isaac's Stone', an offshore rock claimed by mutineer Isaac Martin. A Polynesian male who arrived on the Bounty was murdered at a place called 'Timiti's Crack'. Many places recall accidents and death, 'Where Dan Fall', 'McCoy's Drop', 'Broken Hip' and 'Where Minnie Off', or descriptors of artificial structures like 'Big Fence', 'Down the Grave' and 'The Edge'. 'Christian's Cave' is perhaps the most iconic site situated high on the cliff-face overlooking Adamstown. Lead mutineer Fletcher Christian is reported to have spent many an hour 'brooding' over his rebellious actions and that the cave offered a hideaway in case of discovery. ${ }^{10}$ Visitors to the island often ascend the steep and treacherous route to the cave. The latter affords not only spectacular views but represents how people's actions materially spatialise the myth of place by seeking out physical sites representative of myth. Similarly, the 'Hill of Difficulty', a steep half-kilometre incline from Bounty Bay to Adamstown, is an iconic landmark 'nearly unique as a literary allusion that has lent itself as a place name'.${ }^{11}$ This iconic landmark is a 'must' for most visitors whom often refuse the US\$2 quad bike ride to the top. Visitors are often keen to experience the hill 'first-hand', seemingly to substantiate the myth with reality. 'I've waited forty years for this', an elderly British tourist stated on arrival in 2011, 'it's a boyhood dream come true'. Unbeknown to him, the names of all Pitcairners are engraved at intervals on the concrete

\footnotetext{
8 Larsen, 'Performance, space and tourism'.

9 Maria Amoamo, 2012, '(de)Constructing place-myth: Pitcairn Island and the "Bounty" story, tourism geographies', in New Perspectives on Tropical Coastal and Island Tourism Development, special issue of An International Journal of Tourism Space, Place and Environment 15(1): 107-24. 10 Glynn Christian, 1999, Fragile Paradise: The Discovery of Fletcher Christian, Bounty Mutineer, Sydney: Doubleday.

11 Robert W. Kirk, 2008, Pitcairn Island, The Bounty Mutineers and their Descendants, A History, Jeffersen, NC: McFarland \& Co., p. 134.
} 
sections of the hill, starting with the oldest resident's name at Bounty Bay Landing and ending with the youngest at the top. The road was only paved in 2005, previously being described as a 'gruelling slog up the rough track sliced out of the cliff face'. ${ }^{12}$ Upon landing, Ian Ball stated, 'We stood at last on the little lip of rock and shingle that had been Fletcher Christian's first landfall on Pitcairn' ${ }^{13}$ We can, to some extent then, view tourists seeking a Pitcairn experience as those who chase myths. ${ }^{14}$ The 'myth', bound to childhood dreams as in the aforementioned comment, and fuelled by the wealth of existent Bounty literature is reflected in the actual host/visitor experience. The relationship to myth as a mode of analysis is relevant to present-day Pitcairn society and the role tourism plays in its future development.

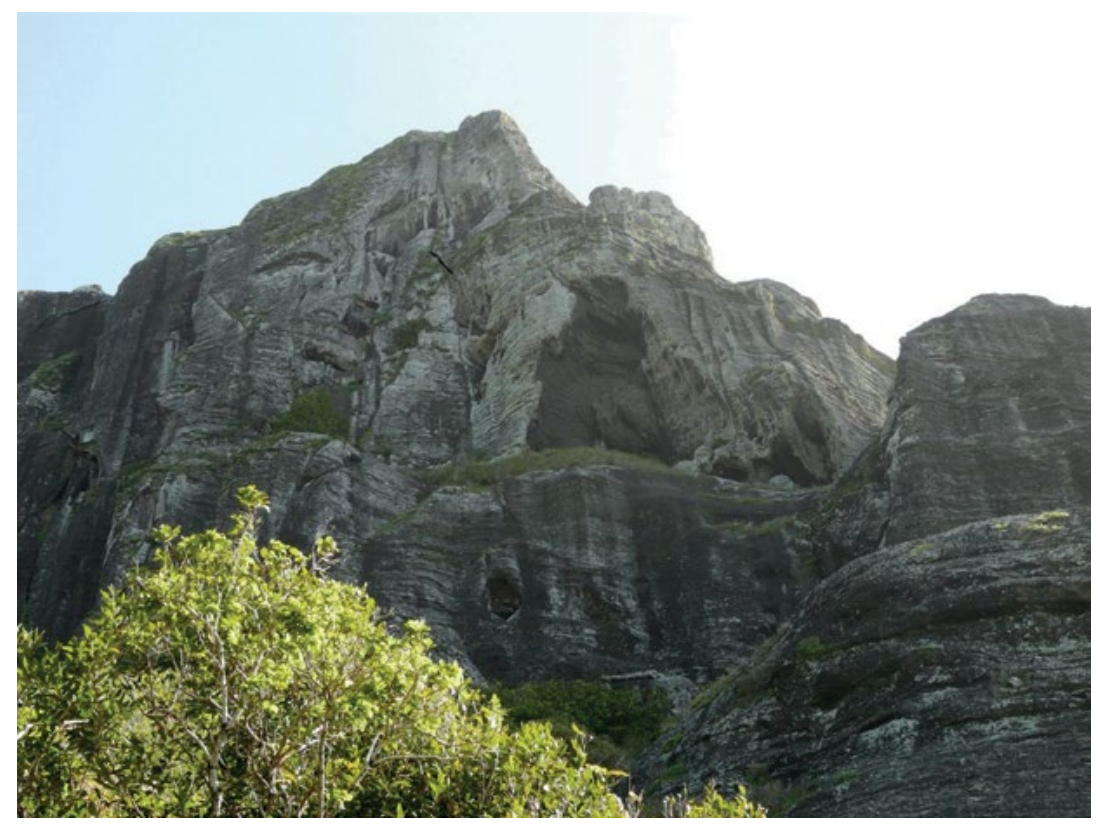

Figure 26. Christian's Cave.

Source. Photographed by Maria Amoamo, Pitcairn Island, 23 January 2009.

12 Ball, Pitcairn, p. 159.

13 Ball, Pitcairn, p. 158.

14 See Tom Selwyn's edited volume, 1996, The Tourist Image Myths and Myth Making

in Tourism, Chichester: John Wiley \& Sons. 
Pitcairn is still, some would say, an island lost in time. Tourists who seek it out are often motivated by a strong will and desire to experience something of the Bounty story; to catch a glimpse of its romantic past and meet first-hand the descendants of these intrepid mutineers. For present-day Pitcairn, the pressing needs of economic development and re-population are the most critical issues for the island's future survival. The fragility of Pitcairn's economic base is recognised by the islanders, who have prioritised tourism as a new focus sector for attracting income to the island and building a sustainable future for this small Pacific Island community.

\section{Pitcairn: The social and economic context}
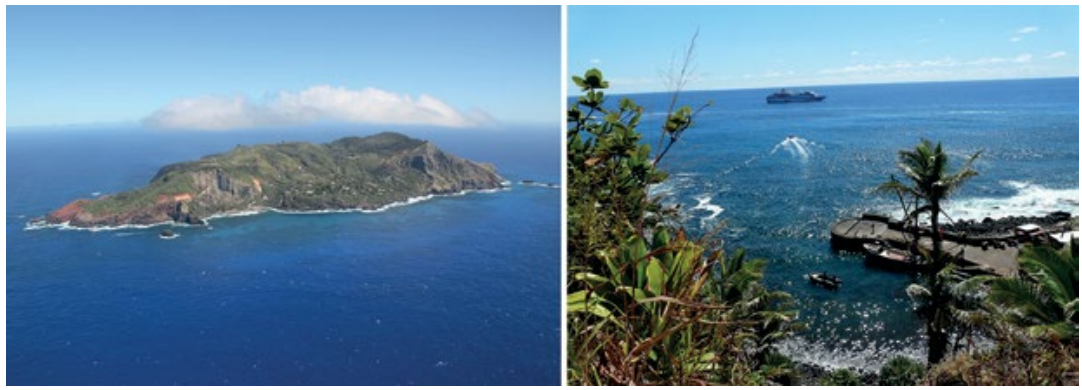

Figures 27 and 28. Pitcairn Island.

Source. Photographed by Maria Amoamo, Pitcairn Island, 23 February 2013.

Situated halfway between New Zealand and South America, Pitcairn is often referred to as one of the most isolated islands in the world. Its tiny size, rugged coastline and sheer cliffs offer no safe anchorage for ships that must lie a mile or two offshore. ${ }^{15}$ Transport to the island is governed by the skill of local men and their longboats. Due to Pitcairn's remote location there is no air strip and access to the island is by ship, a journey of 36 hours from Mangareva, French Polynesia's far-flung archipelago of Gambier Islands. The current service operates only four times a year and has continually been a barrier to economic growth. A handful of cruise ships, charter vessels and yachts visit

15 Pitcairn is $3.2 \mathrm{~km}$ ( 2 miles) long by $1.6 \mathrm{~km}$ ( 1 mile) wide with an irregular shape of which only 8 per cent is flat and its highest point 347 metres (1,138 feet). The Pitcairn Island Group is a British Overseas Territory including Henderson, Ducie and Oeno Islands. Oeno and Ducie are small low atolls while Henderson is a much larger raised coral island and a UNESCO world heritage site. 
the island annually. Today, Pitcairn's populace is dwindling. Out of necessity, cooperative work is more important at times than in more 'traditional' communities elsewhere. ${ }^{16}$ According to Godfrey Baldacchino such resourcefulness and resilience counters the alleged structural vulnerabilities of such small island sites. ${ }^{17}$

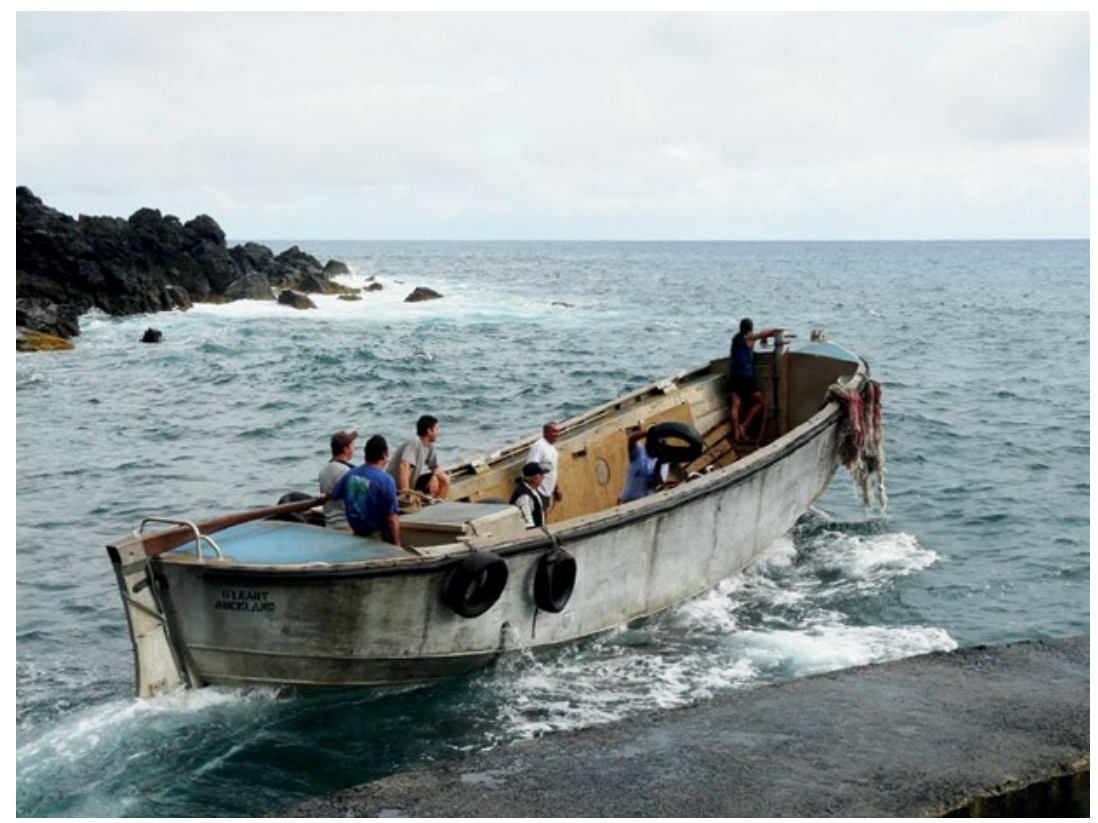

Figure 29. Pitcairn longboat.

Source. Photographed by Maria Amoamo, Pitcairn Island, 31 August 2008.

Pitcairn's economy is heavily dependent on a small number of activities. Much of the islander's day to day life is committed to maintaining roads, building homes, upkeep of basic infrastructure, gardening, government jobs, fishing, trading on ships, taking care of the family and household duties. ${ }^{18}$ The islanders support themselves by making handicrafts, which they sell primarily to cruise ship passengers or those who arrive on small chartered vessels. Pitcairn men produce fine wooden carvings including figures such as sharks, whales, dolphins,

16 John Connell, 1988, 'The end ever nigh: Contemporary population change on Pitcairn Island', GeoJournal 16(2): 193-200, p. 194.

17 Godfrey Baldacchino, 2005, "The contribution of "social capital" to economic growth: Lessons from Island jurisdictions', The Round Table 94(1): 31-46.

18 Pitcairn Islands Administration, 1999, Guide to Pitcairn, Auckland: Government of the Islands of Pitcairn, Henderson, Ducie and Oeno. 
turtles and walking sticks, whilst the women weave intricate baskets, fans, hats and mats, as well as painted dried 'hattie' leaves. Carved replicas of the Bounty and longboats are particular favourites with visitors and can fetch several hundred dollars each. Pitcairn's main economy has been derived from philately, but decline in the demand for stamps has resulted in a need to develop other sources of income. The promotion of the Pitcairn domain name (.pn) is proving to be one source of government income, along with the production and export of local honey. ${ }^{19}$ The Bounty image is by far the strongest motivational factor that attracts visitors, but key challenges for the community include the need to diversify economic activity. Tourism studies have identified the main potential for tourism development on Pitcairn to be carefully managed cruise tourism, long-stay VFR/study/volunteer tourism, short-stay and special interest tourism (e.g. ecotourism) and yachting tourism..$^{20}$ Several locals offer homestay accommodation to visitors and the growth of this sector would significantly benefit local incomes.

In 2009, a government restructure devolved operational responsibility for local governance to the community and aims to develop a more self-sufficient local economic model giving attention to biosecurity, education, public health, agriculture and fisheries, culture and tourism. Outmigration, primarily to New Zealand, has thinned the population from a peak of 233 in 1937 to its present number of 49 and there is a crucial need for repopulation to meet these objectives. Pitcairn is heavily reliant on UK budgetary aid (planned to be $£ 2.9$ million for the year 2012/13) administered by the Department

19 Pitcairn Islands Administration, 2008, Pitcairn Islands Governance Restructure Concept Document, Auckland: Government of the Islands of Pitcairn, Henderson Ducie and Oeno.

20 See Tourism Resource Consultants, 2005, 'Pitcairn Island Tourism Development Feasibility Study', Wellington: FCO Overseas Territories Department and Pitcairn Island Administration; Tourism Resource Consultants, 2008, 'Pitcairn Island 2008 cruise ship survey', Auckland. One option currently under negotiation is the creation of a marine reserve in Pitcairn waters, an EEZ area of some 836,000 square kilometres $(322,781$ square miles). Lobbying by Pew Environmental Group supported by a four-week National Geographic expedition to the islands in 2012 revealed Pitcairn's marine ecosystem to be one of the most pristine in the world. See Eric A. Sala et al., 2012, Pitcairn Islands Expedition Report, National Geographic Society and Pew Environmental Group. The creation of a marine reserve and the existing world heritage designation of Henderson could help Pitcairn develop ecotourism products and build a stronger brand image in the global marketplace. 
for International Development (DFID). ${ }^{21}$ This provides the support and services of contracted professionals, including a doctor, school teacher, community advisor, NZ police officer and the UK Governor's Representative. Furthermore, European Union funds have been approved to build an alternative harbour to help increase tourists landed and to support the development of the tourism sectors in terms of infrastructure improvements, other services and marketing. These proposed projects hope to increase the flow of tourism to the island. Great Britain has until now subsidised Pitcairn but it is uncertain whether it will continue to underwrite the expenses of its tiny but costly colony.

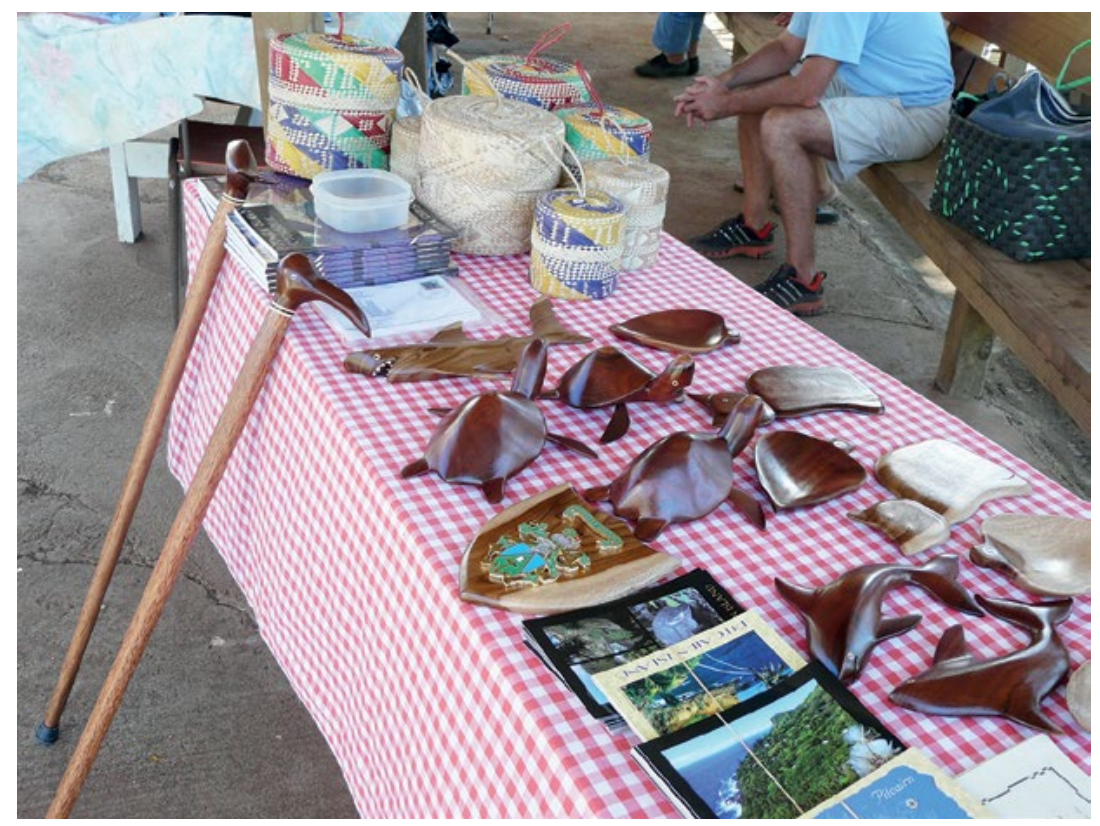

Figure 30. Pitcairn crafts.

Source. Photographed by Maria Amoamo, Pitcairn Island, 19 September 2008.

21 Ian Dickie, Guy Whiteley and Adam Dutton, 2012, Revised Final Draft Report: Economic Analysis of Marine Reserve Designation in Pitcairn Islands' Waters, London: Economics for the Environment Consultancy, August. 


\section{Performing place: Enacting myth}

One example of the intersection of the senses in people's encounters with places is the tangible landscape of Pitcairn - which is also transferrable. That is, when islanders take their souvenirs and handicrafts to visiting cruise ships, it is not unusual for locals to 'bring' Pitcairn to visitors. That is, the tangible dimension of Pitcairn is transported in the form of Pitcairn soil; thus allowing cruise passengers to say they have 'walked on Pitcairn soil'. This performance establishes a connection with the physical (Pitcairn Island) and between host and guest in the touristic encounter. Many tourists actively seek out Pitcairners who are direct descendants of mutineers - the chance to be photographed with a local whose surname is 'Christian' holds resonance with, and gives evidence of, the literary connection. Some male islanders have also created a new type of image - that of the Pitcairn 'pirate', a figure replete with abundant jewellery (pierced and otherwise) as well as sporting the renowned 'tatow' (the term used by William Bligh when describing the Tahitian body tattoos). Female cruise passengers are especially keen to be photographed beside such male 'images'. Here is an example of the creation of 'new' myth (pirates were never part of the Bounty saga). Furthermore, John Urry links tourism and photography with constituting a self-reinforcing closed circle of representation, in which tourist photographs both reflect and inform destination images. ${ }^{22}$ This also aligns with Roland Barthes' notion that myth is not just confined to oral speech; photography also serves to support mythical speech. ${ }^{23}$ According to Jean-François Lyotard, such performance also links with creating a type of 'phantasy' through new motifs. ${ }^{24}$ Such motifs highlight that locals engage with their audience using a particular image to provide a convincing vision. We might conclude that a level of commodification is perpetuated through such performative acts.

22 John Urry, 1990, The Tourist Gaze: Leisure and Travel in Contemporary Societies, London and New York: Routledge.

23 Roland Barthes, 1972, Mythologies, trans. Annette Lavers, New York: Hill and Wang.

24 Jean-François Lyotard, 1989, 'Figure foreclosed', trans. David Macey, in The Lyotard Reader, ed. Andrew Benjamin, pp. 69-110, Oxford: Basil Blackwell. 


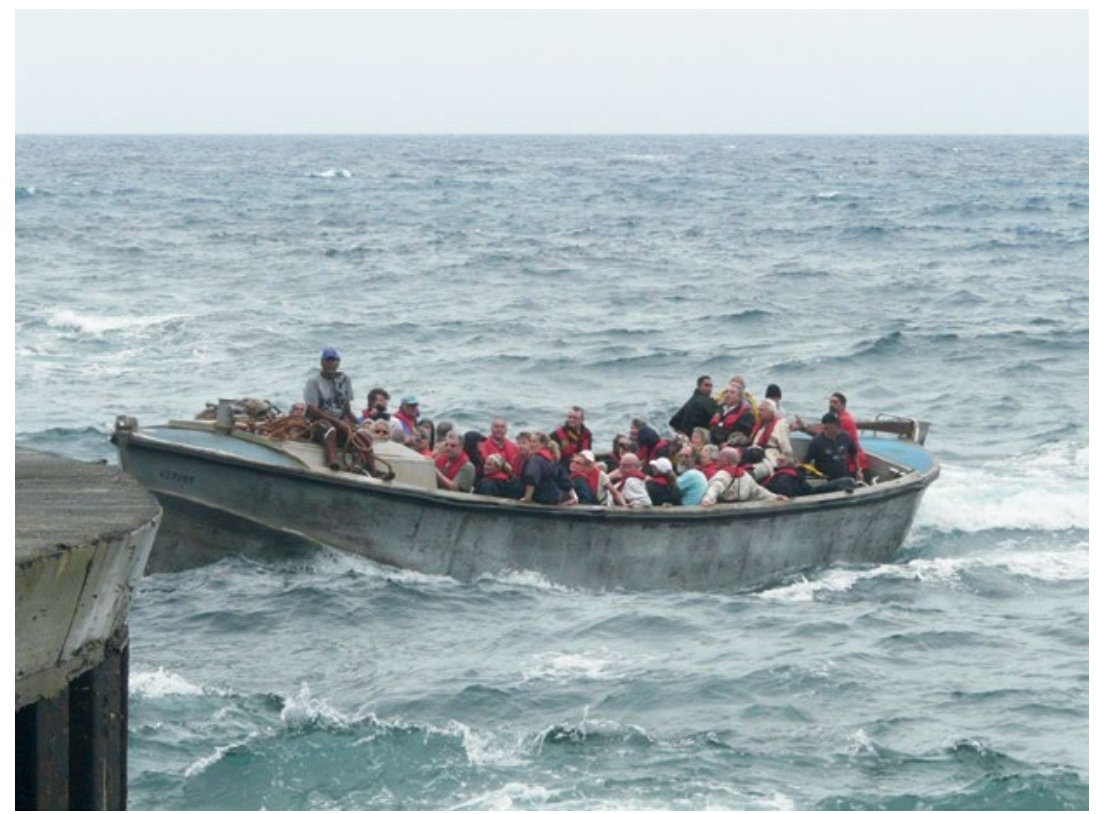

Figure 31. Cruise ship passengers arrive at Bounty Bay.

Source. Photographed by Maria Amoamo, Pitcairn Island, 19 September 2009.

When possible the transfer of cruise passengers onshore is undertaken by Pitcairn longboat - an 'attraction' that has, through historical imagery (literature, stamp issues), become an iconic symbol of Pitcairn culture. The symbolic is also reified in the ritual singing by islanders of the 'farewell song' as the longboat circles a departing ship. Passengers crowd the side of a ship to wave whilst transfixed on the visual and aural spectacle of both Pitcairner and longboat; an activity that embodies Tom Selwyn's notion of myth making. ${ }^{25}$ Selwyn contextualises this type of setting or context in the cultural milieu in which contemporary tourism operates and the search for the authentic. ${ }^{26}$ The ritual, performed less often today from longboat, has been transferred to onboard performance whereby Pitcairners often congregate together in a performative space and sing the many popular hymns and songs that epitomise the Bounty heritage. These performances connect to, and reflect, the past and present mythology of Pitcairn as the iconic 'utopia' created in the nineteenth century. The host/visitor

25 Tom Selwyn, 1996, 'Introduction', in The Tourist Image Myths and Myth Making in Tourism, ed. Tom Selwyn, pp. 1-32, Chichester: John Wiley \& Sons, p. 28.

26 Selwyn, 'Introduction', p. 29. 
interaction reflects to some extent how tourist destinations are places where fantasies and myth are superimposed on landscapes. Tourists arrive at their destination with their own agendas, prepared to make their tourist sites conform to their fantasies and gazes, recruiting their 'subjects' so to speak. In addition, such performances add to a certain understanding they (Pitkerners) have of themselves.

\section{Concluding remarks}

Chris Rojek and John Urry argue that 'myth and fantasy play an unusually large role in the social construction of all travel and tourist sights' ${ }^{27}$ The latter serves to organise, on the one hand, the tourist 'gaze', its expectations and observations, and on the other hand, the institutions, policies and workings of the community/place/space that is being gazed upon. The development of a greater diversity of economic activity is the key challenge for Pitcairn, with the current focus on reducing isolation, providing opportunities for economic growth and ensuring basic services. John Gillis reminds us, 'It is one of the great paradoxes of our times that the value of remoteness increases even as modern communications make all parts of the world more accessible' ${ }^{28}$ As this once isolated community, hidden from the world, emerged in the public imagination in the early nineteenth century, the 'myth' surrounding Pitcairn has grown ever larger. Today, remoteness offers both advantages and obstacles, however 'myth making' continues to contribute to how Pitcairn might endeavour to secure a sustainable future for its handful of inhabitants.

\section{References}

Agnew, John. 1987. Place and Politics: The Geographical Mediation of State and Society. London: George Allen and Unwin.

27 Chris Rojek, 1997, 'Indexing, dragging and the social construction of tourist sights', in Touring Cultures: Transformations of Travel and Theory, ed. Chris Rojek and John Urry, pp. 52-74, London: Routledge, p. 53.

28 John Gillis, 2004, Islands of the Mind, New York: Palgrave MacMillan, p. 152. 
Amoamo, Maria. 2012. '(de)Constructing place-myth: Pitcairn Island and the "Bounty" story, tourism geographies.' In New Perspectives on Tropical Coastal and Island Tourism Development. Special issue of An International Journal of Tourism Space, Place and Environment 15(1): 107-124.

Baldacchino, Godfrey. 2005. "The contribution of "social capital" to economic growth: Lessons from Island jurisdictions.' The Round Table 94(1): 31-46.

Ball, Ian M. 1973. Pitcairn: Children of the Bounty. London: Gollancz.

Barthes, Roland. 1972. Mythologies, trans. Annette Lavers. New York: Hill and Wang.

Benjamin, Andrew (ed.). 1989. The Lyotard Reader. Oxford: Basil Blackwell.

Christian, Glynn. 1999. Fragile Paradise: The Discovery of Fletcher Christian, Bounty Mutineer. Sydney: Doubleday.

Clarke, Peter. 1986. Hell and Paradise: The Norfolk, Bounty, Pitcairn Saga. Ringwood: Viking.

Connell, John. 1988. 'The end ever nigh: Contemporary population change on Pitcairn Island.' GeoJournal 16(2): 193-200.

Dickie, Ian, Guy Whiteley and Adam Dutton. 2012. Revised Final Draft Report: Economic Analysis of Marine Reserve Designation in Pitcairn Islands' Waters. London: Economics for the Environment Consultancy. August.

Fullerton, William Young. 1923. The Romance of Pitcairn ... Illustrated. London: Carey Press.

Gillis, John. 2004. Islands of the Mind. New York: Palgrave MacMillan.

Hayward, Philip. 2006. Bounty Chords: Music, Dance and Cultural Heritage on Norfolk and Pitcairn Islands. Eastleigh: John Libbey Publishing.

Kirk, Robert W. 2008. Pitcairn Island, The Bounty Mutineers and their Descendants, A History. Jeffersen, NC: McFarland \& Co. 
Larsen, Jonas. 2012. 'Performance, space and tourism.' In The Routledge Handbook of Tourism Geographies, ed. Julie Wilson, pp. 67-73. Abingdon, Oxon: Routledge.

Lyotard, Jean-François. 1989. 'Figure foreclosed.' Trans. David Macey. In The Lyotard Reader, ed. Andrew Benjamin, pp. 69-110. Oxford: Basil Blackwell.

Pitcairn Islands Administration. 1999. Guide to Pitcairn. Auckland: Government of the Islands of Pitcairn, Henderson Ducie and Oeno.

- 2008. Pitcairn Islands Governance Restructure Concept Document. Auckland: Government of the Islands of Pitcairn, Henderson Ducie and Oeno.

Rojek, Chris. 1997. 'Indexing, dragging and the social construction of tourist sights.' In Touring Cultures: Transformations of Travel and Theory, ed. Chris Rojek and John Urry, pp. 52-74. London: Routledge.

Rojek, Chris and John Urry (eds). 1997. Touring Cultures: Transformations of Travel and Theory. London: Routledge.

Royle, Stephen A. 2001. A Geography of Islands Small Island Insularity. London: Routledge.

Sala, Eric, Alan M. Friedlander, Enric Ballesteros, Eric Brown, Heather Bradner, Jennifer Caselle, Michael Fay and Alan Turchik. 2012. Pitcairn Islands Expedition Report. National Geographic Society and Pew Environmental Group.

Selwyn, Tom (ed). 1996. The Tourist Image Myths and Myth Making in Tourism. Chichester: John Wiley \& Sons.

Selwyn, Tom. 1996. 'Introduction.' In The Tourist Image Myths and Myth Making in Tourism, ed. Tom Selwyn, pp. 1-32. Chichester: John Wiley \& Sons.

Tourism Resource Consultants. 2005. 'Pitcairn Island Tourism Development Feasibility Study.' Wellington: FCO Overseas Territories Department and Pitcairn Island Administration.

— 2008. 'Pitcairn Island 2008 cruise ship survey.' Auckland. 
6. PITCAIRN AND THE BOUNTY STORY

Urry, John. 1990. The Tourist Gaze: Leisure and Travel in Contemporary Societies. London and New York: Routledge.

Wilson, Julie (ed.). 2012. 'The Routledge Handbook of Tourism Geographies. Abingdon, Oxon: Routledge. 
This text is taken from Touring Pacific Cultures, edited by Kalissa Alexeyeff and John Taylor, published 2016 by ANU Press, The Australian National University, Canberra, Australia. 